\title{
Kutanöz leishmaniasis ve Hatay ílindeki durumu
}

\section{Cutaneous leishmaniasis and its status in Hatay province, Turkey}

\author{
Gülnaz ÇULHA ${ }^{1}, \quad$ Çiğdem Asena DOĞRAMACl ${ }^{2}$, Burcu GÜLKAN ${ }^{1}, \quad$ Nazan SAVAŞ ${ }^{3}$
}

\begin{abstract}
ÖZET
Amaç: Yurdumuzda Güneydoğu Anadolu Bölgesi ve Çukurova yöresinde endemik olarak görülen kutanöz leishmaniasis (KL) yıllardır önemini koruyan bir halk sağlığı problemidir. Çalışmada 2006-2011 yılları arasında Hatay il Sağlık Müdürlüğü ve Mustafa Kemal Üniversitesi Araștırma Hastanesi Parazitoloji Laboratuvarı verilerinin birlikte analizi ile Hatay ilinde $\mathrm{KL}$ olgularının ve odaklarının belirlenmesi amaçlanmıștır.
\end{abstract}

Yöntem: Parazitoloji Laboratuvarına Ocak 2006Temmuz 2011 tarihleri arasında farklı polikliniklerden KL şüphesiyle başvuran 596 hastadan smear örnekleri alınmıștır. Ayrıca lezyonun süresi, sayısı, yeri, hastanın yașı ve yerleșim yerini (ilçe ve köy olarak) içeren bilgi formları doldurulmuștur. KL şüpheli lezyonlardan smear yapılarak, Giemsa boyası ile boyanmıș, 100X immersiyon objektifi ile mikroskop incelemesi yapılarak parazitin amastigot formu görünen olgulara pozitif KL tanısı konmuștur. İstatistiksel yöntemlerde ki kare testi kullanılmıștır.

Bulgular: İncelenen 596 olgudan 273 (\%45,8)'ü KL açısından pozitif bulunmuștur. Pozitif olguların $139(\% 50,9)$ 'u kadın, 134 (\%49,1)'ü erkek hastadır. Olguların 39 (\%14,3)'unda birden fazla lezyona rastlanmıștır. Lezyonun kadınlarda baș-boyun ve gövde kısmında daha çok $(p=0,036, p=0,240)$ erkeklerde

\section{ABSTRACT}

Objective: Cutaneous leishmaniasis $(\mathrm{CL})$, which is endemic in the South-East Anatolia and Cukurova areas, has been an important public health problem for years. This study is an: analysis of Mustafa Kemal University, Research Hospital, Parasitology Laboratory and Hatay Provincial Health Directorate's data collected between years 2006-2011, to determine more recent cutaneous leishmaniasis sources in Hatay province and reasons for this increasing trend.

Method: Smear samples were collected from 596 patients who applied to the Parasitology Laboratory in between January 2006-July 2011. Information forms including the lesion's duration, number, location (as providence and village), patient's age and location have been filled. In cases suspected of cutaneous leishmaniasis, a smear was performed, stained with Giemsa and microscopy examination was performed with 100X immersion objective. Positive $C L$ recognition was placed on cases when the amastigot form of parasite was observed. Ki square test was used for statistical analyses.

Results: Two hundred seventy three cases of 596 patients ( $45.8 \%$ of patients) were found to be $C L$ positive. One hundred thirty nine $(50.9 \%)$ of positive cases were female and 134 (49.1\%) of positive cases were male. Thirty nine $(14,3 \%)$ of 273 positive cases have more than

\footnotetext{
' Mustafa Kemal Üniversitesi, Tıp Fakültesi, Parazitoloji Ana Bilim Dalı, HATAY

${ }^{2}$ Mustafa Kemal Üniversitesi, Tıp Fakültesi, Dermatoloji Ana Bilim Dalı, HATAY

${ }^{3}$ Mustafa Kemal Üniversitesi, Tıp Fakültesi, Halk Sağlığı Ana Bilim Dalı, HATAY
}

\section{İletişim/Corresponding Author : Gülnaz ÇULHA Mustafa Kemal Üniversitesi, Tıp Fakültesi, Parazitoloji Ana Bilim Dalı, HATAY} Tel : +903262291000 E-posta/E-mail : gulnazculha@yahoo.com 
bacakta daha fazla olduğu $(p=0,014)$ saptanmıștır. KL tanısı konan yaș gruplarının 0-12 yaș $73(\% 26,7)$ ve 13-24 yaș arasında $89(\% 32,6)$ kiși olduğu, lezyon süresinin çoğunlukla 0-6 ay arasında bulunduğu saptanmıștır. Hatay il Sağlık Müdürlüğü'ne 2006-2011 yılları arasında yapılmış tüm bildirimler incelenmiș, Mustafa Kemal Üniversitesi Hastanesi Parazitoloji Laboratuvarından yapılan bildirimler dişındaki hastaların kayıtları da incelenmiștir. Toplam 269'u erkek, 266'sı kadın hasta olmak üzere 535 hasta belirlenmiștir. İ Sağlık Müdürlüğü verilerinde yaș, cinsiyet, yașadığı ilçe yanısıra hastanın kliniğinin değerlendirildiği gözlemlenmiștir.

Sonuç: Hatay'da önceki yıllara göre KL'nin yeni enfeksiyon odaklarının varlığı tespit edilmiștir. $\mathrm{Bu}$ odakların Hassa, Samandağı ve Altınözü ilçelerinde ve özellikle Suriye sınırına çok yakın olan köylerde olmasının Hatay'da olgu sayısını daha da artırabileceğini düșündürmektedir. Bu nedenle KL saptanan ilçe ve köylerde düzenli aralıklarla tarama yapılması, kayıtların düzenli tutulabilmesi ve tedavilerinin sağlanması için ilı Sağıık Müdürlüğü ile birlikte tanı ve tedavi konusunda eğitimler verilmesinin gerektiği sonucuna varılmıștır.

Anahtar Kelimeler: Kutanöz leishmaniasis, Hatay, yayma one lesion. The lesion locations of head, neck and trunk were most commonly involved among women $(p=0,036$, $\mathrm{p}=0,240$ ), on the other hand leg was most common side on men $(p=0,014)$. CL commonly observed at ages between $0-12$ in 73 (26.7\%) cases, and ages between 13-24 in $89(32.6 \%)$ cases. Most of the lesion durations were between 0-6 months. All the cases notified to Hatay Provincial Health Directorate between years 2006 2011 were assessed except the cases belong to Mustafa Kemal University, Research Hospital, Parasitology Laboratory. Total of 535 patients (269 men, 266 women; including our patients) were notified. It is noticed that Provincial Health Directorate's data includes only age, gender, year and town and also clinical features of the patient.

Conclusion: In Hatay, unlike previous years, presence of new $\mathrm{CL}$ focal points were observed. These cases are concentrated at Hassa, Samandağı and Altınözü towns and particularly at regions very close to Syrian border. These locations could be the reasons for increased number of $\mathrm{CL}$ cases. For this reason performing periodical screenings at the provinces and towns where $\mathrm{CL}$ was diagnosed should be realized. Moreover, giving seminars and educational sessions were planned in collaboration with Hatay Provincial Health Directorate.

Key Words: Cutaneous leishmaniasis, Hatay, smear

birbirine bağlayan bir konumda olması ayrıca çok çeșitli iklimsel ve coğrafik karaktere sahip bulunması leishmaniasis epidemiyolojisi açısından önemli bir yer tutmaktadır. Leishmaniasisin ülkemizde en çok görülen șekli KL'dir. Güneydoğu Anadolu ve Akdeniz Bölgelerinde endemik olan ve etken olarak şimdiye kadar Leishmania tropica'nın bilindiği KL olgularına ayrıca Leishmania major veya Leishmania infantum tiplerinin de neden olabileceği son vektör ve izoenzim analizleriyle gösterilmiștir (3-9). 
Türkiye'nin Güneydoğusunda Çukurova Bölgesinde yer alan Hatay Ili 5.403 km²'lik bir alanı kapsamaktadır. Şehrin \%46'sını dağlar, \%33'ünü ovalar oluşturur. Batıda Akdeniz'e kıyısı olup Suriye ile de uzun bir sınırı paylașmaktadır (10). Hatay ilinde yaz mevsiminin uzunluğu, tropikal iklim koșullarının hüküm sürmesi ve bol nem, KL olgularının artmasına sebep olmaktadır. Kum sineklerinin (Sand flies) yaşaması için uygun iklim ve coğrafik koșulları sağlayan Hatay Ilinde halk geçimini daha çok hayvancılık ve tarımdan sağlamaktadır (10, 11). Hatay'da tespit edilen $K L$ olgularının sayısı 19982005 yılları arasında en yüksek seviyeye (1.079 kişi) ulașmıştır (11). Hatay il Sağlık Müdürlüğü verilerine göre 2005-2011 yılları arasında hasta sayısında bir düșüș görülmekle birlikte hastalığın yeni odakları da saptanmıștır. Yeni odaklarının Hassa, Altınözü ve Samandağı ilçelerinde belli köylerde (Yuvalı, Alahan, Kıyıgören, Meydan) olması Hatay'da KL olgularının sayısının artışında bölgenin sosyal özelliklerinin önemli rolü olabileceğini düșündürmüștür.

Bu çalıșmada 2005-2011 yılları arasında Hatay il Sağlık Müdürlüğü ve Mustafa Kemal Üniversitesi Parazitoloji Laboratuvarından bildirimi yapılan verilerin birlikte analizi ile Hatay İlinde KL'nin yeni odakları ve bu odaklardaki artış nedenlerinin ortaya konulması amaçlanmıștır.

\section{GEREÇ VE YÖNTEM}

Mustafa Kemal Üniversitesi Parazitoloji Laboratuvarına Ocak 2006 - Temmuz 2011 tarihleri arasında KL şüphesi ile 596 hasta başvurmuștur. Hazırlanan hasta bilgi formu her hastaya rutin olarak uygulanarak hastaların yașı, yerleșim yerleri, ahırlarının olup olmadığı, lezyonun; süresi, sayısı, kaydedilmiştir. Hesaplamalar yapılırken SPSS programı kullanılmıştır.

Örnek alınırken alkolle silinip kurutulduktan sonra lezyon kenarına 15 numaralı bistüri ile $0,5 \mathrm{~cm}$ uzunluğunda, 2-3 mm derinliğinde bir insizyon yapılmış ve bu insizyonun iç kısmının bistüri ile kazınması sonucu elde edilen kansız-seröz materyal lama yayılarak metil alkolle tespit edildikten sonra Giemsa boyasıyla boyanmıștır. Mikroskobik inceleme için X100 immersiyon objektifi kullanılarak bir hücre duvarı ile çevrili sitoplazma içerisinde nükleus ve kinetoplasttan oluşan Leishmania amastigot cisimciği aranmıștır. Ayrıca klinik olarak şüpheli olan fakat alınan smear örneklerinde Leishmania amastigot cisimciği tespit edilmeyen olgularda insülin enjektörü yardımıyla örnek alınarak modifiye NNN+RPMI 1640 besiyerinde kültürleri yapılarak Leishmania promastigot formu aranmıștır $(1,10)$.

Hatay Il Sağlık Müdürlüğü’nün 2006 - 2011 yılları arasında yapılmış tüm bildirimleri incelenmiş, Mustafa Kemal Üniversitesi Hastanesi Parazitoloji Laboratuvarından yaptığımız bildirimler dışında olan hastaların kayıtları da incelenmiștir. Bu kayıtlarda 269'u erkek, 266'sı kadın hasta olmak üzere 535 hasta (Mustafa Kemal Üniversitesi Hastanesi Parazitoloji Laboratuvarından yaptığımız bildirimler dahil)'nın bulunduğu saptanmıștır.

İstatistiksel değerlendirmede ki kare testi kullanılmıştır.

\section{BULGULAR}

Ocak 2006 - Temmuz 2011 tarihleri arasında Mustafa Kemal Üniversitesi Tıp Fakültesi Parazitoloji Laboratuvarına KL şüphesiyle bașvuran toplam 596 hastadan smear örnekleri alınmıştır. Smear veya kültürleri (sekiz olgu) pozitif olan 139 (\%50,9)'u kadın, 134 (\%49,1)'ü erkek olgu olmak üzere 273 olguya $\mathrm{KL}$ tanısı konmuștur. Olgularda cinsiyetler arasında istatiksel olarak bir fark bulunamamıștır $(p=0,11)$.

Olguların 39 (\%14,3)'unda birden fazla lezyona rastlanmıştır. Lezyon yerlerine göre dağııında kadınlarda baș-boyun ve gövde kısmında daha çok olduğu, erkeklerde bacakta daha fazla olduğu $(p=0,001)$ saptanmıştır (Tablo 1). Mikroskop incelemesinde 
amastigot belirlenen ve $\mathrm{KL}$ tanısı konan; 0-12 yaș aralığında 73 (\%26,7), 13-24 aralığında $89(\% 32,6)$ olgu bulunduğu (Tablo 2) lezyon sürelerinin çoğunlukla 0-6 ay arasında olduğu izlenmiștir. Ayrıca; 100 (\%36,6) olgunun hayvanları olduğu ve ahırların evlerinin yakınında olduğu öğrenilmiștir. $64(\% 23,4)$ kișinin öğrenci, $25(\% 9,2)$ kișinin ev hanımı, sekiz $(\% 2,9)$ kișinin çiftçi ve $75(\% 27,5)$ kișinin serbest meslek sahibi olduğu öğrenilmiștir.

Tablo 1. MKÜ Parazitoloji Laboratuvarında 2006-2011 yılları arasında saptanan $\mathrm{KL}$ olgularının lezyon yerleri ve cinsiyete göre dağılımı (Verileri olan 211 olgu)

\begin{tabular}{lcccc}
\hline $\begin{array}{l}\text { Lezyon } \\
\text { Yeri }\end{array}$ & Kadın (\%) & Erkek (\%) & Toplam & $\mathrm{p}^{*}$ \\
\hline $\begin{array}{l}\text { Baș- } \\
\text { Boyun- } \\
\text { Gövde }\end{array}$ & $78(\% 58,7)$ & $55(\% 41,3)$ & $133(\% 62,5)$ & \\
Kol & $24(\% 42,1)$ & $33(\% 57,9)$ & $57(\% 27)$ & 0.001 \\
Bacak & $4(\% 19)$ & $17(\% 81)$ & $21(\% 10)$ & \\
\hline Toplam & $106(\% 50,2)$ & $105(\% 49,8)$ & $211(\% 100)$ & \\
\hline
\end{tabular}

${ }^{*}$ Kikare test

Tablo 2. MKÜ Parazitoloji Laboratuvarında 2006-2011 yılları arasında saptanan $\mathrm{KL}$ olgularının yaș grubu ve cinsiyete göre dağılımı

\begin{tabular}{llll}
\hline Yaș & Kadın (\%*) & Erkek (\%*) & Toplam $\left(\%{ }^{* *}\right)$ \\
\hline $0-12$ & $40(\% 54,8)$ & $33(\% 45,2)$ & $73(\% 26,73)$ \\
$13-24$ & $40(\% 44,9)$ & $49(\% 55,1)$ & $89(\% 32,60)$ \\
$25-36$ & $13(\% 44,8)$ & $16(\% 55,2)$ & $29(\% 10,62)$ \\
$37-48$ & $13(\% 36,1)$ & $23(\% 63,9)$ & $36(\% 13,18)$ \\
$49-60$ & $15(\% 65,2)$ & $8(\% 34,8)$ & $23(\% 8,42)$ \\
$61-72$ & $10(\% 83,3)$ & $2(\% 16,7)$ & $12(\% 4,39)$ \\
$73->$ & $8(\% 72,7)$ & $3(\% 27,3)$ & $11(\% 4,02)$ \\
\hline TOPLAM & $139(\% 50,91)$ & $134(\% 49,9)$ & $273(\% 100)$ \\
\hline
\end{tabular}

* Satır yüzdesi ** Sütun yüzdesi
Altınözü'nden $47(\% 17,2)$, Hatay merkezden 54 $(\% 19,8)$, Hassa'dan 35 (\%12,8), Samandağ'dan 28 $(\% 10,3)$, Yayladağ'dan $22(\% 8,1)$, İskenderun'dan 42 $(\% 15,4)$ Kırıkhan'dan $38(\% 13,9)$ ve Reyhanlı'dan 5 $(\% 1,8)$ olgu tespit edilmiștir. Özellikle 2009 yılına kadar Hassa (özellikle Yuvalı Köyü), Antakya (özellikle Alahan Köyü), Altınözü (özellikle Kıyıgören Köyü) ve Samandağ (özellikle Meydan Köyü), ilçelerinde nadiren olgular saptanırken 2009 yılından itibaren olgu sayısındaki kayda değer artışla birlikte bu bölgeler yeni KL odakları olarak belirlenmiștir (Șekil 1-3).

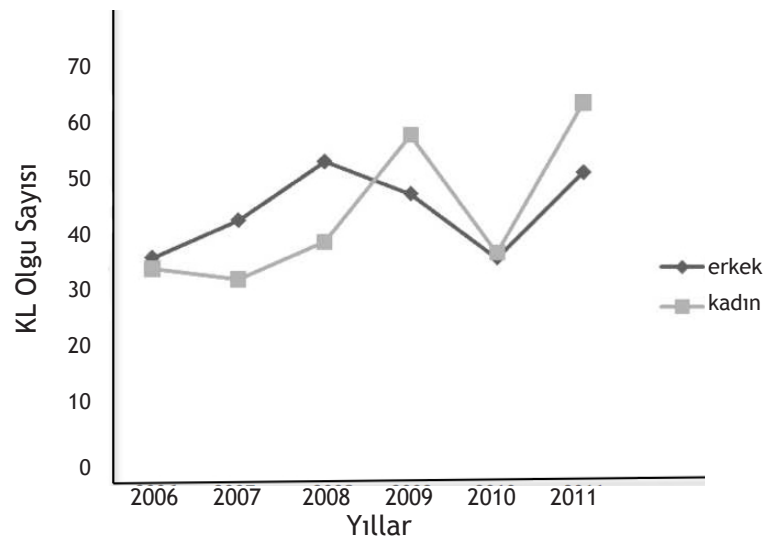

Şekil 1. 2006-2011 yılları arasında saptanan KL olgularının yıllara göre dağılımı. (Hatay il Sağlık Müdürlüğü verileri bizim verilerimizle birlikte verilmiștir 535 olgu)

\section{TARTIȘMA}

KL bașta Şanlıurfa İli olmak üzere Güneydoğu Anadolu Bölgesinde hiperendemik, Çukurova Bölgesinde ise endemik bir hastalık olarak yıllardır hüküm sürmektedir. Göçlerin ve seyahatlerin artması, kentler arası ulaşımın kolaylaşmasıını yanı sıra vektör kum sineklerine karșı yürütülen mücadelenin yetersiz kalması gibi nedenlerle hastalığın insidansında tekrar bir artış gözlendiği bilinmektedir $(2,3)$. Hatay illinde yeni odak olarak belirlenen köylerde halkın birçoğunun gerek ticaret gerekse gezi amaçlı hastalığın endemik olduğu Suriye'ye eskiye göre daha sık giriş-çıkış yapmalarının olgu sayısının artışında rol oynayabileceğini düşündürmektedir. 


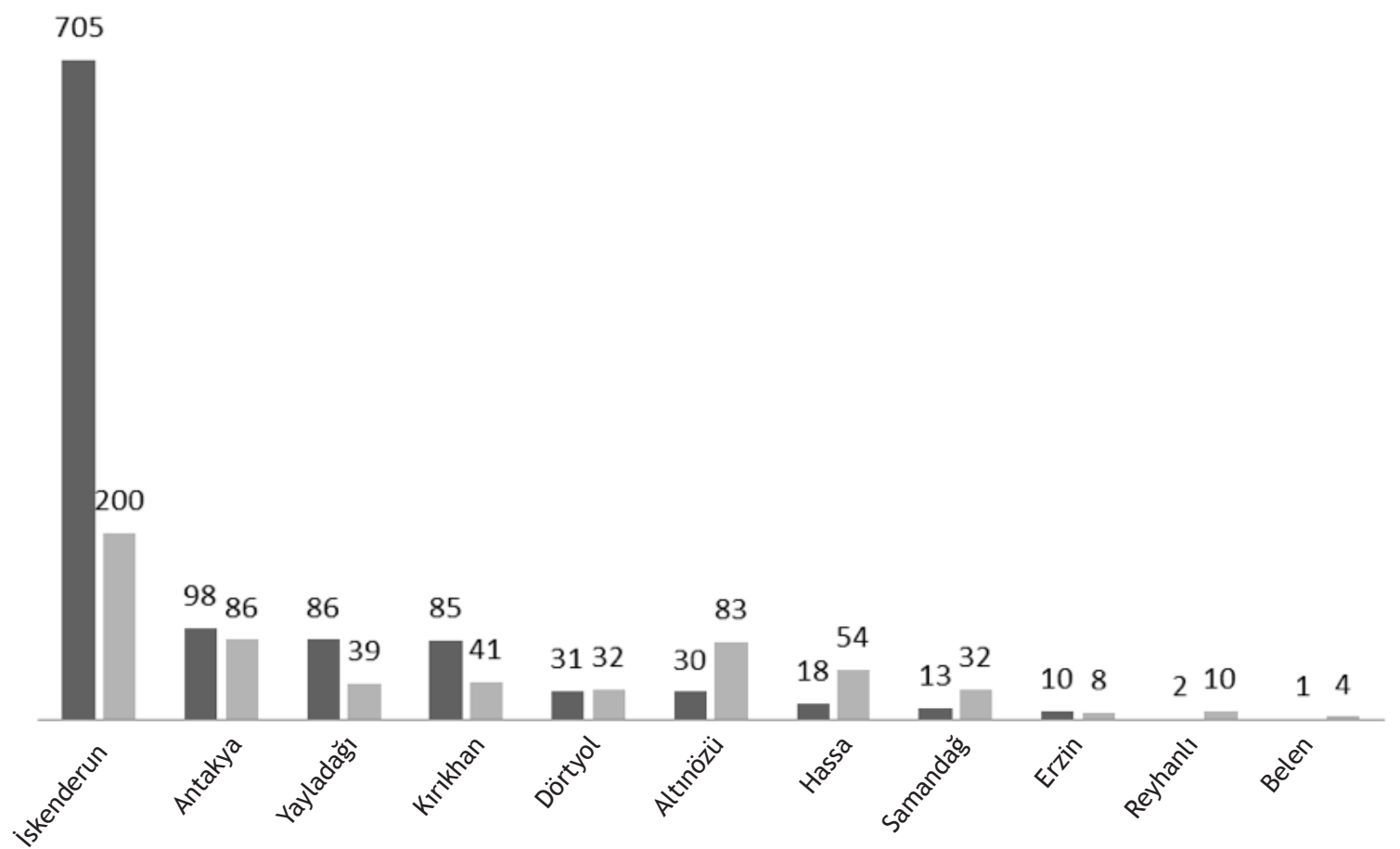

Şekil 2. İlçelere göre 1998-2005 [-Akçalı ve ark. (11)] ve 2006-2011 yılları arasında saptanan KL olgularının ilçelere göre dağılımı (il Sağlık Müdürlüğü kayıtları ve bizim verilerimizle birlikte verilmiștir).

L. major'ün etken olduğu $\mathrm{KL}$ olgularında L. tropica'ya göre daha kısa sürede iyileșme görülmektedir. L. major'de 2-4 ayda iyileșme görülürken bu süre $L$. tropica' da 6-15 ayı bulmaktadır. KL lezyonları klinik olarak fronkül, ektima gibi bakteriyel deri enfeksiyonları ile sıkça karıșabilir. Enfekte böcek ısırı̆ğ, diskoid lupus eritematosus, lupus vulgaris, derin mantar infeksiyonlan ve deri maligniteleri de ayırıcı tanıda düşünülmelidir. Yanlış tanı koyma riskinin olması nedeniyle klinik olarak KL tanısı mutlaka bir laboratuvar yöntemi ile doğrulanarak kesinleștirilmelidir $(12,13)$.

Mustafa Kemal Üniversitesi Hastanesine KL şüphesi ile başvuran hastalar için hazırlanan Hasta Bilgi Formu'yla 2006 yılından beri düzenli olarak hasta bilgileri kayıt altında tutulmaktadır. Bu formun KL'nin yeni odaklarının belirlenmesinde oldukça yararlı olduğu düşünülmektedir.

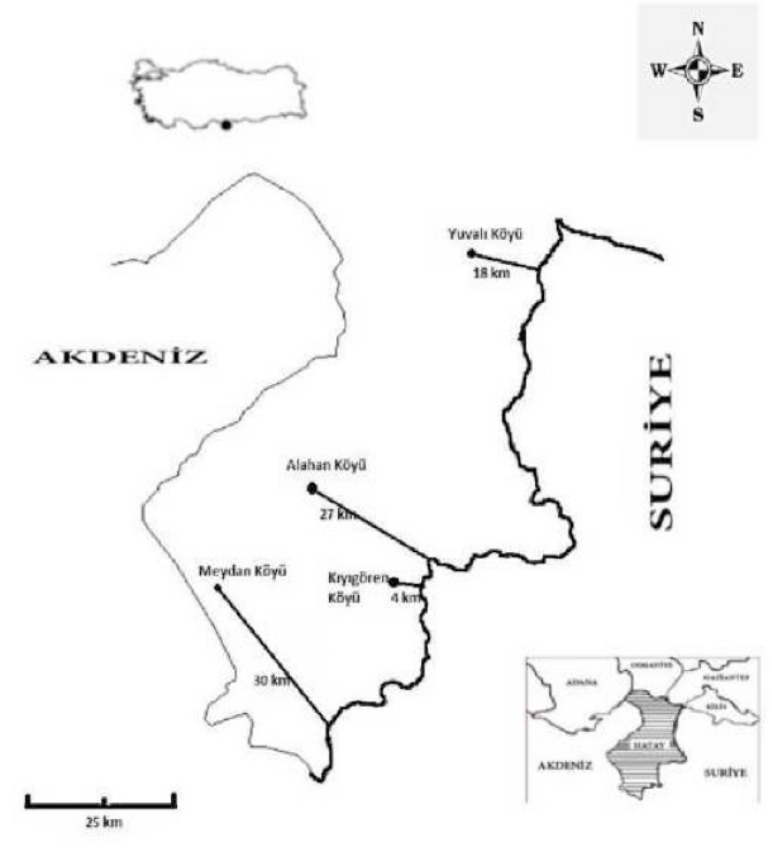

Şekil 3. KL'nin Hatay İlinde saptanan yeni yerleșim yerleri ve Suriye sınırına olan mesafeleri $(\mathrm{km}$ olarak verilmiștir). Hassa Yuvalı Köyü, Antakya Alahan Köyü, Altınözü Kıyıgören Köyü, Samandağ Meydan Köyü) 
Başvuran hastaların çoğunluğunu 0-24 yaș arasındaki genç ve çocuklar oluşturmaktadır. KL tanısı konulan 273 olgunun 139'u kadın 134'ü erkektir. Ayrıca bölgemizde olguların çoğunlukla 15 yaș altı çocuklardan oluștuğu bilinmektedir $(12,14)$.

Mikroskop incelemesinde amastigot saptanarak KL tanısı konmuş olguların 39 (\%14,3)'unda birden fazla lezyon yeri tespit edilirken, 234'ünde ise tek lezyon belirlenmiștir. KL'de lezyonların bizim olgularımızda da daha çok elbise dıșında kalan baș-boyun bölgesi gibi açık vücut bölgelerinde yerleșmiș olması (tüm lezyonların $\% 56,5^{\prime}$ i) hastalığın vektörü kum sineklerinin aktivasyon yetenekleri ile ilișkilendirilebilir. KL nedeniyle başvuran $100(\% 36,6)$ kișinin hayvancılıkla uğraștığı ve ahırlarının evlerinin yakınında olduğu tespit edilmiștir. Illimizde saptanan yeni odaklar da kum sineklerinin ekolojik koșullarını sağlayan uygun habitatların olușturduğu söylenebilir.

Yaman ve ark. 2001 yılında kum sineklerine yönelik çalıșmalarında Haziran-Kasım ayları arasında Hatay'ın; Erzin, Dörtyol, İskenderun, Kırıkhan, Antakya, Samandağ, Altınözü ve Yayladağı ilçelerine kurdukları yapışkan tuzaklarla Phlebotomus ve Sergentomyia türlerine ait 998 kum sineği yakaladıklarını bildirmişlerdir (14).

Bizim çalışmalarımızda da hastaların çoğunun kırsal kesimlerden geldiği, yaz aylarında damlarda uyuduğu ve kum sineğine karșı herhangi bir önlem almadığı gözlenmiștir. Rutin olarak her hastaya uyguladığımız hasta bilgi formunda başvuran kişilerin evinin tek katlı ve bahçeli olduğu belirlenmiş olup bu durumun uçma yeteneği zayıf olan kum sineklerinin insanlara ulașmasını kolaylaștırdığı düşünülmektedir. Ayrıca olguların \%36,6'sının hayvancılıkla uğrașması ve hayvan barınaklarının evlerinin yakınında olması da riski arttırmaktadır.

Birçok ilde yapılan araștırmalar incelendiğinde araștırmacılar KL olgularının artmakta olduğuna dikkat çekmektedirler. Sucaklı ve ark. 2002-2006 yılları arasında Diyarbakır'da, il Sağlık Müdürlüğü kayıtlarına göre $1.990 \mathrm{KL}$ olgusu olduğunu bildirmişler ve bu bölgedeki morbidite hızının Türkiye'den fazla olduğuna dikkat çekmișlerdir (15). Hastalığın ülkemizdeki en önemli endemik odağı olan Şanlıurfa'da 1983 yılında 1.741 olgu saptanmıs ve bu tarihten sonra daha önce sporadik olan Çukurova Bölgesi de endemik hale gelmiștir. Bu durum büyük oranda iki bölge arasında geçici göçlerle karakterize bir sosyal olgu olan mevsimsel tarım ișçiliği ile ilișkilendirilmiștir. KL Șanlıurfa'da 1997-2000 yılları arasında ortalama yıllık 1.000 olgu ile azalmıș olmakla birlikte 2004 yılında 2.290 olgu ile yeniden üst seviyeye ulașmıștır $(16,17)$. Yapılan araștırmalarda bu bölgede de hastalığın bizim bulgularımıza paralel biçimde daha çok 5-19 arası yaș grubu etkilediğini görmekteyiz. Akçalı ve ark.'nın 1998 -2005 yılında Hatay'da yaptığı kapsamlı çalıșmada toplam 1.079 olgu tespit edilmiștir (11). Bunlardan en yüksek oranda $705(\% 65,34)$ olgu ile ilk sirada İskenderun sonrasında sırasıyla Antakya merkezde 98 (\%9,08), Yayladağı'nda $86(\% 7,97)$, Kırıkhan'da 85 $(\% 7,88)$, Altınözü'nde $30(\% 2,80)$, Hassa'da $18(\% 1,67)$, Samandağ'da 13 (\%1,2), Reyhanlı'da iki $(\% 0,19)$, ve Belen'de bir $(\% 0,09)$ olgu tespit edilmiştir. 1998-2005 yılları arasında $18 \mathrm{KL}$ sadece Hassa'dan bildirilmiștir (il Sağlık Müdürlüğü verileri). Bizim çalıșmamızda 20062011 yılları arasında Hassa'da saptanan 27 olgunun 20'si Hassa'ya bağlı Yuvalı Köyünde bulunmaktadır (Şekil 2). Aynı șekilde 1998-2005 yılları arasında 30 KL sadece Altınözü'nde (Il Sağlık Müdürlüğü verileri) belirlenmiștir. 2006-2011 yılları arasında Altınözü'nde 83 olgu saptanmıș bunların 25'i Kıyıgören Köyü olarak tarafımızdan bildirilmiștir. Samandağı ilcçesi'nde 1998-2005 yılları arasında 13 olgu bulunurken, 20062011 yılları arasında 32 olgu saptanmış ve bunların 20'si Meydan Köyü olarak tarafımızdan bildirilmiștir (Şekil 2).

Bildirim sistemimizdeki eksiklikler, kayıtların düzenli olarak tutulamaması KL hakkındaki bilgilerimizin sağlıklı olmamasına yol açmaktadır. Örneğin il Sağlık 
Müdürlüğü’ndeki 2006-2011 yıllarına ait KL olgu sayıları incelendiğinde olguların yalnızca geldikleri ilçe, yaș cinsiyet ve tarih bilgilerinin not edildiği gözlenmiștir. Bu nedenle î Sağlık Müdürlüğü yetkilileri ile görüșülmüș hazırladığımız ayrıntılı bilgi formlarının kullanılması önerilmiştir.

Yeni odak köylerinin Suriye sınırına olan mesafesine bakıldığında Kıyıgören Köyü’nün 4 km, Yuvalı Köyü’nün 21 km, Meydan Köyü’nün 30 km, Alahan Köyü’nün 30 km olduğu saptanmıștır. Mesafelerin sınıra yakın olması, Suriye'den geçiș olasılığını düșündürmüștür.

Yeni odak yerlerinin yanı sıra ilimizin merkez ilçesi dahil olmak üzere tüm ilçelerinde düzenli aralıklarla tarama yapılması KL deki asıl artıșı belirlememize yardımcı olacaktır. Bu konuda hasta bilgilerinin daha düzenli kayıt altına alınması gerektiği düșünülmektedir. Ancak sağlık ocaklarında çalıșan görevlilerin KL konusunda eğitim almıș olsalar da yerlerinin devamlı değișmesi, yeni gelenlerin eğitim almaması, çalıșan personel yetersizliği ya da olmayıșı eldeki verilerin güvenirliğini azaltmaktadır. Bu konuyla ilgili olarak daha sık eğitim verilmesinin, bildirim açısından d kolaylık sağlayacağını düșündürmektedir.

Sonuç olarak bu çalıșmada da ortaya konduğu gibi son yıllarda görülen $\mathrm{KL}$ olgu sayılarındaki artış alınan önlemlerin yetersizliğini göstermektedir. Bu artışın önüne geçilebilmesi için kum sineklerine karşı mücadelenin arttırılması, rezervuar konak görevi gören köpeklerin belirlenmesi ve tedavi edilmesi, halkın şark çıbanı olarak bildiği KL hastalığına karșı eğitim programları düzenlenerek bilinçlendirilmesi ve tespit edilen olguların tedavilerinin tam olarak yapılmasının gerektiği düşünülmektedir. Ayrıca ilimizden KL'nin endemik olduğu yerlere gidiș geliș çok fazla olmaktadır. Örneğin tașımacılık yapan șoförler, turistik amaçlı çıkanlar, mevsimlik işçi olarak gelenler sayılabilir. Bu konuda yine il Sağlık Müdürlüğü ile görüşülmüş, bu vakaların erken tespit edilmesinin önemi vurgulanmıștır.

\section{TEŞEKKÜR}

Hatay il Sağlık Müdürlüğü’ne çalıșmada gösterdikleri ișbirliği ve yardımları için teșekkür ederiz.

\section{KAYNAKLAR}

1. World Health Organization. Report of the Scientific Working Group on Leishmaniasis. Geneva. World Health Organization, 2004; 5-6.

2. Güngördü H, Uzun S. Leishmaniasis. Turkiye Klinikleri J Dermatol-Special Topics, 2010; 3(2): 40-3.

3. Gürel MS, Yeșilova Y, Ölgel MK, Özbel Y. Cutaneous leishmaniasis in Turkey. Türkiye Parazitol Derg, 2012; 36(2): 121-9.
4. Akman L, Aksu HS, Wang RQ, Özensoy S, Özbel Y, Alkan Z, et al. Multi-site DNA polymorphism analyses of Leishmania isolates define their genotypes predicting clinical epidemiology of leishmaniasis in a specific region. J Eukaryot Microbiol, 2000; 47(6): 545-54.

5. Svobodovâ M, Alten B, Zidkovâ L, Dvorák V, Hlavacková J, Mysková J, et al. Cutaneous leishmaniasis caused by Leishmania infantum transmitted by Phlebotomus tobbi. Int J Parasitol, 2009; 39(2): 251-6. 
6. Baz K, Köktürk A,Türsen Ü, Kaya Ti, İkizoğlu G, Kanık A. Cutaneous leishmaniasis in Anamur. Turkiye Klinikleri J Dermatol, 2002; 12(1): 5-10.

7. Serin MS, Waki K, Chang KP, Aslan G, Direkel S, Otag $\mathrm{F}$, et al. Consistence of miniexon polymerase chain reaction-restriction fragment length polymorphism and single-copy gene sequence analyses in discriminating Leishmania genotypes. Diagn Microbiol Infect Dis, 2007; 57(3): 295-9.

8. Malatyalı E, Özçelik S, Gürsoy N. Kekik (Thymus vulgaris), kimyon (Cuminum cyminum) ve Mersin (Myrtus communis) bitkilerinden elde edilen yağların in vitro anti-leishmanial etkileri. Türk Hij Den Biyol Derg, 2009; 66(1): 7-13.

9. Bayazıt Y, Özcebe H. Șanlıurfa ili kent merkezinde kutanöz leishmaniasis insidans ve prevalansı. Türk Hij Den Biyol Derg, 2004; 61(1,2,3): 9-14.

10. Çulha G, Akçalı C. Detection of cutaneous leishmaniasis cases in Hatay and surrounding areas. Turkiye Parazitol Derg, 2006; 30(4): 268-71.

11. Akçalı C, Çulha G, İnalöz S, Savaș N, Önlen Y, Savaș $\mathrm{L}$, et al. Cutaneous leishmaniasis in Hatay. J Turk Acad Dermatol, 2007; 1(1): 1-5.
12. Uzun S. Leishmaniasis. Ed. Tüzün $Y$, Gürer $M A$, Serdaroğlu S, Oğuz O, Aksungur VL. Dermatoloji. 3. baskı İstanbul, Nobel Tıp Kitabevi, 2008; 659-82.

13. Ceyhan AM, Meriç G, Aynalı G. A Case of cutaneous leishmaniasis mimicking squamous cell carcinoma. Türkderm, 2012; 46(1): 44-6.

14. Yaman M, Özbel Y. The sandflies (Diptera: Psychodidae) in the Turkish province of Hatay: Some possible vectors of the parasites causing human cutaneous leishmaniasis. Ann Trop Med Parasitol, 2004; 98: 741-50.

15. Sucaklı MB, Saka G. Epidemiology of cutaneous leishmaniasis in Diyarbakir. Turkiye Parazitol Derg, 2007; 31(3): 165-9.

16. Gurel MS, Ulukanligil M, Ozbilge $H$. Cutaneous leishmaniasis in Sanliurfa: Epidemiologic and clinical features of the last four years (1997-2000). Int J Dermatol, 2002; 41(1): 32-7.

17. Yemisen M, Ulas Y, Celik H, Aksoy N. Epidemiological and clinical characteristics of 7172 patients with cutaneous leishmaniasis in Sanliurfa between 2001 and 2008. Int J Dermatol, 2012; 51(3): 300-4. 